\title{
The University under the Pressure of Innovation Policy - Reflecting on European and Finnish Experiences
}

Marja Häyrinen-Alestalo

The analyses of the transformations in state responsiveness to socio-economic determinants indicate that the policies aiming at regulating the developments of various sectors have becomeincreasingly interdependent. Currently economic and industrial policies, mostly in the form of technology/ innovation policy, provide key ideas for other policies. Concomitantly, the national governments in Western Europe together with the OECD and the European Union regard science and university policiesasintegral parts of innovation policy which in turn is pursued "to guarantee sustainable economic growth under changing societal conditions" (European Commission, 1998:14)

Recently, thepenetration of utilitarian arguments into governments' university policy has been so intensive that even the concept of scientific curiosity has been replaced by the concept of innovation. In the political context the con- cept of innovation refers now to a process whereall producers of knowledgeare involved in every phase of an innovation chain, i.e. from the production of knowledge to its marketing and commercialisation. There has also been pressure on the universities to redefine their goals, values and missions in order to demonstrate their contribution to economic progress and social welfare, and their value as a public investment.

In this paper I make an effort to scrutinise some theoretical premises that have been constructed to explain the university'scurrent situation. Moreover, I analyse the main arguments of innovation policy by the OECD and the EU and describe their reflections and relevance to the national strategies of Finland. Finally, I illustrate the responsiveness of the university to government aspirations by demonstrating the ways three differentFinnish universities have reacted to growing utilitarian demands 
and the goals and strategies they have chosen to specify their roles as promoters of innovation policy.

\section{How to Explain the Increasing Transparency of Technology Policy?}

From a sociological point of view, the shift in the orientations by the governments points to a need to construct and reconstruct relevant macro-level theories and to test their validity by making comparisons on manylevels. In a political system various groups of actors have various opportunities to make decisions about resources and to control thefunctioning of the system. It has become increasinglynecessary to establish flexible structures of interaction and responsibility to achieve a consensus about the primary aims and to construct alternative strategies. According to Friedman only the growth of evolutionary interdependence can end at an equilibrium of various strategies (Coleman, 1990:2931).

The analyses of political programs in Europe, especially as regards the attemptsto democratisethe social system of the welfare state, reflect attempts of the political system trying to achieve a consensusamong the relevantactors on the issues of social importance. However, innovation policy has its roots in economic and technology policies and due to increasing neo-liberal orientations of national and supranational organisations, competitive models of performance have begun to serve as models for all kinds of social institutions and groupings. Thereforetheinteraction patterns contain new elements of asymmetry (Alestalo, 1997) arising from the utilitarian and market-driven attempts to identify the winners from the losers. Moreover, irrespective of the demand for new transactions and contracts between the partners (mostly in the form of deregulation and decentralisation), the maximisation of economic utility has been used by the governments as an imperative to make the activities more effective.

The latest policy programs in Europe demonstrate that these kinds of strategies arefocused to changegovernments' orientations, formulate more coherent supranational and national strategies and affect the contents of sectoral policies (European Commission, 1995; 1998; OECD, 1996; Ministry of Trade and Industry, 1996; Europe:TheThird Way/Die Neue Mitte, 1999). A closer look reveals a multiplicity of visions and prospects of the future that are driven by highly advanced innovations/technologies. In a way the visions are based on social theory as a plenty of references has been made to some "postmodern" elements of socio-economic change. In particular the political views of "the information society" (Blair, 1998; Sitra, 1998) and "the globalizing learning economy" (European Commission, 1998) have served as syntheses of the new technology-intensive social, economic and human progress.

Today these views have become superconcepts under which almost all progressive aspects of modernisation have been gathered. However, with the use of superconcepts the political formulations have lost their theoretical value. Mostly they reflect only limited political strategies, as the utopian component has been overly emphasised and the critical component has remained underdeveloped (Häyrinen-Alestalo, 
1999). Surely, one can find attempts to strengthen the critical side of these visions (as the references to the reshaping of new social exclusions demonstrate) but the projects of the information society and the globalizing learning economy are full of valid and non-valid premises.

According to the EU's terminology the main aim in Europe today is to understand the role that technology and innovation play in the economy, i.e. in the economy that is globalizing and becoming increasingly based on knowledge and learning (European Commission, 1998: 3). In this view "national innovation systems" are regarded as comprising all knowledge producing activities whether they are products of the universities or of other institutions focusing to advance learning capabilities. In this way government's university policy has become subordinate to technology policy and there is a pressure to include a learning component in innovation policy (see also Allardt, 1998a).

Theories Trying to Illustrate the University's Contribution to Innovation Policy

Recently, the concept of Triple-Helix by Leydesdorff and Etzkowitz (1996;1998) and the attempts to explain a new mode of production of academic knowledge (the Mode 2) by Gibbons et al. (1994) havedominated thetheory-formulation of new university-government-industry linksin the field of sciencestudies. Even though they illustrate many features of the current political demands for the deepening and creation of new functional dependencies between the university, the state and the enterprises as well as thetransactions between various policies, these constructions have remained mainly on the level of a metatheory. Rather than openingsound theoretical ways to make empirical specifications, they have concentrated on the programmatic side of theory construction. In a way they present a similar simplified political program for universityindustry relationships as did the theory of "science as a direct productive force" in the 1970s (Richta, 1977).

The key idea in the Triple-Helix and the Mode 2 type activities is the need to createa new world of interactions beside the traditional academic world; a world where theinterpenetration of utilitarian and instrumental needs of knowledge and information into the academic world isnatural, easy and worth promoting both by the governments and by the enterprises. In particular the Triple Helix model is an attempt to demonstrate the convergence and crossings of technology policy over university policy by referring to a spiral model of innovation which is based on a close interaction between the university and the production sector. In the model the final convergence will be a combination of the actors, institutions, and the rules and regulations (Viale \& Ghiglione, 1998).

Also in the Mode 2 many assumptions have been made to figure out an innovation relevant model for scientific activities. The model is characterised by the demand-side of knowledge production, government- and industry-driven needs of information as well as interdisciplinary and heterogeneous research networks across a wide range of organisations (Gibbons et al., 1994; Fuller, 1998). The role of the university in these kinds of configurations becomes prob- 
lematic as academic activities should be increasingly organised around the solving of utilitarian problems. The criteria of good performancearethereforeoften only evidences of technical skills of the Mode 2 type of problem solving (Ziman, 1996).

According to the Triple Helix theory, the university which has always been relatively marginal in its orientation to experimental sciences, should figure out its relevance to technology policy and build up new programs of collaboration for education and research. As the government and industry are interested in promoting innovation-based activities, it is left to the university to solvetheconflict between paradigm-driven and innovation policy-driven search for knowledge (see also Fuller, 1998; Nieminen, 1998). Moreover, the hypotheses on the dynamics of the state activities are inconsistent in reflecting the key ideas of modern theories of the state. The main attention is on the conception of the state that resembles a neo-liberalistic definition (e.g. European Commission, 1994). In the Triple Helix and Mode 2 types of models the state is a kind of an one-dimensional actor, a mediator and coordinator of interests from the enterprise sector to the universities. However, in the real political world theneo-liberal state has also been willing to control the performance of public institutions, including the universities. Moreover, the current Social Democratic governments in Europe have tried to develop a new scenario of a non-controlling, challenging state (Europe: The Third Way/Die NeueMitte, 1999). In order to explain the state's role in the Triple Helix configurations, it is thereforenecessary to explore the ideological changes of governments' and the waysnew divisions of power and labour between the partners in the new interactions can be established.

Along with the growing transparency of technology policy over university policy the representatives of the Triple Helix have paid attention to the need to strengthen theentrepreneurial activities of the university (Etzkowitz et al., 1998). This requirement means that the transactions between the university and the enterprises should imitate the process of capitalisation of knowledge. Up until now therehas been a few systematic discussions about what kinds of products and services the academic community should produce to fulfil this requirement.

Because of strong programmatic biases of the Triple Helix and the Mode 2, it is necessary to explore how the relevant partnersare able to act and where the limits to expand university's responsiveness to economic and pragmatic issues should be drawn. Firstly, it is necessary to analyse the actual role of the university as a producer of knowledge. Irrespective of the growing criticism of the Mode 2 type of knowledge production (e.g. Allardt, 1998b; Jacob, 1997; Fuller, 1998; Ziman, 1996), the problem of epistemic autonomy and thehypothesis of two contradictory ways of creating scientific knowledge are still open questions. If the social value of science is increasingly determined on the basis of this conflict, the identity of scientific activities becomes diffuseand therange of the criteria by which the university can legitimateitsvalue as the main producer of knowledge, becomes limited.

Secondly, as regards to the ideological components of political programs, the relationships between institutional 
settings and ideologies become important. By reflecting the proceedings of the second international TripleHelixconferencein 1997, Etzkowitz and Leydesdorff (1998) distinguish three types of Triple Helices of which two refer to theimpacts coming from the institutional spheres of the universities, governments and industries. Nevertheless, there is still limited information about the ways the institutional dependencies are related to ideological issues. Among others, in the midst of neo-liberal policy the state is responsive to different socio-economic determinants than, for example, when thethird sector with its demands for new horizontal divisions of power and labour is supposed to become a reality (see Giddens, 1998; Blair, 1998). Thenew configurations of actors will not be necessarily the ones which are searched for today.

Finally, it isworth paying attention to the enterprise sector and to its dependency on the structures of economy and industry. Irrespective of the arguments for the globalizing economy, only some branches of industry are today able to contribute to the goals of innovation policy. Moreover, the problem of how to produce marketable services in order to compensateindustrial activities has not been solved in the visions of technology policy in a coherent way. Any transformation of the basic economic structures will change the key premises of innovation policy. Therefore, it is important to ask, whether theTripleHelix or the Mode 2 models reflect only traditional peculiarities of industrial society rather than take into account the latest theories of social change that question the traditional tenets of capitalism and point to a crisis of political legitimacy (Castells,
1996; 1997). This issue is actual today as in the new formulations of the welfare state by the Social Democratic governments. They have launched such concepts as "knowledge-based service economy" (Europe: The Third Way/Die Neue Mitte, 1999).

\section{The OECD Policy Integrating Economic Determinants with Science and Higher Education Policies}

After World War II economists in Western advanced countries have developed a variety of theories and economic policy guidelines which have been integrated with national Cabinet programs and with the ones published by the OECD, the GATT and the European Union. In general there has been atrust on science as a productive force. However, at first the attention of economic policy was on the possibilities to transfer technological knowledge to industrial production and on the conditions of higher education to changetheold manufactures into high tech industries. As only a few scientific disciplines were seen capable of taking part in the modernisation of old industries, there was no specific pressure on the multidisciplinary universities to change their approaches. However, in the late 1960s the view of the importance of technology-intensive social action started to penetrate into science and higher education policies. Even though the politicians still hesitated how the goals of well-being and academic freedom should be determined and what is the role of the state in this process. In the words of Belgian Prime Minister Lefèvre (1965:15) who took part in the ministerial "talk about 
science" arranged by the OECD in 1965:

\begin{abstract}
Must we seek scientific advance for its own sake, in the hope of obtaining thus, indirectly, benefits for technology and for the well-being of the state? Or must weengage in systematic pursuit of particular social and economic objectives by means of plans, specifically devoted to the development of science? Should such programs include concern with university education and fundamental research; or should their burden rather be the organisation of applied research?
\end{abstract}

As can be seen, in science and university policies, a certain distance wastaken from economic and technology policies. This attitude was supported later on in the welfare state programs where the state's activities were focused on correcting and regulating the process of socialisation and on guaranteeing the survival of privately controlled exchange processes (Offe, 1996; Alestalo, 1997). Thecontribution to socio-economic development through educational policy was seen more important than the university's direct integration with the promotion of the economy through technology.

In the 1980s, during theeconomicrecession, the OECD's economic policy was revised, "as the inputs to the development and progressive dissemination of new technologies instead of having brought radical changes, have not resulted in a positive effect on economic growth" (OECD, 1988). By adopting the idea of long-cycles in economic development, an attempt was made to guarantee economic growth and to encourage greater exploitation of science and technology as a means of strengthening industrial production and social and cultural development.
In the late 1980s, economic policy emphasising the development, diffusion, transfer, trade and exploitation of technology, started its march as the primarymodel for all kindsof policies. Even though there was a growing pressure to radically transform the climate of academic institutionsto favour technology, it was not yet used as the leading principle in science and university policies. However, of the factors that the OECD (1988:15) saw as the primary componentsinfluencingtechnological innovation, the following were listed:

1. science and technology base of industry

2. the overall allocation by $R \& D$ expenditures between the sectors

3. the system of university-government R\&D establishmentindustry links

4. the functioning of labour markets

5. the responsiveness of capital market to the opportunities of innovation

6. policies affecting trade, competition and market structure

7. the protection of intellectual property rights

As regards the university-governmentindustry links, the diffusion of technology was still the primary aim. Little by little the social and cultural issues became subordinate to the promotion of technological innovations. The universities wereintegrated with these utilitarian goals but their value as cultural institutions was not yet questioned. The state was regarded as a supporter of research activities, as a provider of a relevant infrastructure and as a creator of economic climate which is favourableto technological innovations. 
In the Scandinavian welfarestates the government-regulated university policy was highly concentrated but still mostly orientated to educational issues. Equalisation of opportunities was regarded as the primary goal and labour markets in the public sector provided impacts on the modernisation of the universities. On the European level, in particular the governmentsin Finland, France, Norway and Portugal emphasised the need to expand the university system on the basis of regional policy needs. This process was a combination of the aims to modernise local enterprises and to integrate the new universities with local economic demands (Gueissaz \& Häyrinen-Alestalo, 1999).

\section{The University Responding to New Demands and Supplies}

In Europe the context of the policies that are relevant in creating university-government-industry links and in redefining the basic university functionsis now, in the late 1990s, totally different from that in the late 1980s. On a general level the role of the state has changed as so many European countries are members of the European Union. In the EU there is a pressure "to speak in one voice", to have a common economy that is based on innovations and highly qualified technologies as well as common economic, science and technology policies which aim at fulfilling these aspirations (European Commission, 1994; 1998). The efforts to construct a coherent policy for the development of theEU reflect also a change in the ideology providing the main concepts for policy formulations. This ideology is full of references to neo-liberal premises.
If weconsider separately the actorsin university-government-industry configuration in the context of current political debate, it becomes evident how complicated it is to use the concepts of the Triple Helix or the Mode 2 type production of knowledge. Firstly, the universitiesarenotany more pushed to change their functions to become multiversities and to be responsiveto all kinds of practical needs of education. Along with the ongoing undermining of the public sector which is related to the undermining of the welfare state, the needs of labour force in this sector have collapsed. Together with the pressure to privatize public services, there are new demands to strengthen the awareness about the problem of employment at the higher education institutions. However, the universities cannot take the primary responsibility of regulating the educational needs of labour force as the other actors, the state and the enterprises, do not exactly know what these needs will be. The universities are also the only public institutions which must balance socio-economic needs of education with their other basic function: to providescientific education in order to strengthen the capabilities of doing research. This requirement means that the conflict between academic education and research has to be discussed in a systematic way.

From the Triple Helix viewpoint it is necessary to ask: Do the governments and enterprises actually support the university in fulfilling its basic functions? What means of quality control have they to offer to the university? Can university policy be renovated using the criteria of innovation policy?

From the Mode 2 type of argumentation it is also relevant to pose the follow- 
ing questions: How should academic education meet the challenges of industry-driven activities? If there is a pressure to integrateresearch into teaching, what kind of research should be integrated into teaching and what should be taught? Can the institutionalisation of two opposite modes of knowledge production (Mode 1 and Mode 2) increase the university's competitiveness on the knowledge production markets?

The state and the enterprises have begun to ask more evidence of the capacity of the academic community to takepart in theongoingsocietal "rationalisation" process. This effort originated from the demands of competition, privatisation and deregulation intended to push all public institutions, the universityas well, to beaware of theinvestment and use value of their activities. In particular the experiences of the UK and Finland demonstratethat the state is no more willing to act as a guarantor of the production of non-market and nonprice products (Häyrinen-Alestalo \& Snell, 2000). Even in thecase of state-led university system, non-market products are now seen as to refer to disciplinarybased, paradigm-driven activities and to socio-cultural issues that do not need the shelter of the state.

In recent years both thestateauthorities on national and supranational levelsand therepresentatives of enterprises havediscussed theimportance of modifying economic growth theories and views of technical change. This discussion is worth analysing, as specific assumptions of economic theory have an impact on the ways the university-government-industrylinkagescan beestablished. In many Western countriesa neoclassical model of economic growth has been used to argue for a steady-state growth equilibrium where the growth is determined by the rate of technological change. However, the role of technological changewasleft unexplained, asit was treted exogenous. Concomitantly, technology was a kind of a black box preventing the control of the rate of its progress and the way it interacted with growth (Rojo, 1996).

The rise of new growth theories (Grossman \& Helpman, 1991; Romer, 1986) has introduced behaviour equations which reflect belief in the importance of processes such as learning-bydoing, research and development, spillovers, education and human capital improvement. In the policies of the OECD (1996), the EU (1995; 1998) and of many European nation-states (e.g. Ministry of Trade and Industry, 1996; 1997; Europe: TheThird Way/ DieNeue Mitte, 1999) the new emphasis on behavioural components has indicated a shift in theproduction function by industry in $R \& D$ to create knowledge-based economies. As a result thefollowing policy recommendations have been given (Rojo, 1996: 36):

1. taxincentives for entrepreneurs and R\&D activities

2. promotion of education and training capabilities

3. improvement of labour mobility

4. creation of collaborative networks

5. facilitation of the access to small and medium sized enterprises to the innovation market

6. introduction of supporting institution in the innovation market

7. creation of venture capital markets

The new growth theories have been called "endogenous" as they emphasise 
human capital investments. For this reason they seem at the first sight to be favourable for university policy. However, in the new collaboration networks the enterprises are the key actors and the government authorities have the responsibility to alleviate underprovisions bylowering market risks. From the viewpoint of university policy these aspirations are a sign of a growing marginalisation of traditional university functions.

\section{European University as a Collaborator in the European Innovation System}

Despite of a high technology policy relevance, the new growth theory has provided weak empirical evidence of itself. According to Soete (1996: 8-9) a kind of a new growth paradox has become evident:

a paradoxical relationship is emerging between, on the one hand, the new found formal belief in the importance of theincreasing return associated with research and ideas, identified for example in terms of rivalry and control, of appropriatability and, on the other hand, theempirical evidenceabout the contribution of $R \& D$ - and in particular the public support for R\&D - to output and productivity growth.

In recent years the "knowledge-based society" and the "knowledge-based economy" have been found as useful concepts in political programs in Europe. Also in the EU 's view "the production process has increasingly relied on knowledge-based activities" (European Commission 1998:31). However, as I have pointed out above, the policy formulations refer not any more to the "knowledge-based economy" but to the "globalizing learning economy" (European Commission, 1998: 31):

since the high pace of change means that specialised knowledge becomes much more of a short-lived resource, and that it is rather the capability to learn and adapt to new conditions that increasingly determines the performance of individuals, firms, regions and countries.

Accordingly, the learning economy is supposed to assist the governments in their search for a new, more aggressive innovation policy that is also flexible enough to meet both the defects of economic growth and the asymmetries and uneven distributions of capabilities between the member states. According to these aspirations, individual learning abilities and innovation policiesincluding a learning component are intended to develop competencies to adapt to rapidly evolving market and socio-economic changes. However, innovation as a component of technological progress isstill a diffuse concept as regards itsrelation to scientific progress. In thewords of Edith Cresson (1996:1) who was the Member of the European Commission responsible for research, innovation, education, training and youth,

innovation is Europe's Achilles heel as the economy suffers from an innovation deficit... It has become apparent that what was Europe's great strength in the nineteenth century, namely its capacity to assimilate scientific progress, translate it into technical reality and exploit it commercially, has weakened. It is not that the standard of European researchers has dropped, or that European scientific excellenceisa thing of the past but the innovation chain linking ideas to products, has stackened. 
For the European universities the EU's current strategy to expand the activities understood as innovations and its emphasis on innovation policy, means a growing pressure to link academic activities to collaborations with other knowledge producers. One should also bear in mind that current innovation policy is focused both on the needs to search for new innovations and to speed up the processes of innovation. In principle, these aims have been seen at the EU as pressing and they have given an impact to allocate more funding to science and technology. However, in the 1990s, many nation-states in Europe have cut the funding of the universities' basic functions and allocated more fundsto problem-solving that is relevant for economic and technology policy (EVALUE, Final Report, 1998) ${ }^{1}$.

Along with the new priorities of government funding, it is important to pay attention to the definitions of innovation which are problematic for academic activities. The European Commission (1998: 29) has defined innovation in the following way:

In an essential sense, innovation concerns the search for, and the discovery, experimentation, development, imitation, and adaptation of new products, new production processes and new organisational set-ups.

Accordingly, innovation not only comprises research and education but all the steps which are needed to produce and market new products and information. As the university cannot betransformed into a pure state- and industry-driven factory, the policy-makers have proposed elaboration of networks of a Triple Helix type as well as transactions of functions and responsibilities. As such, the demand for the formation of new alliances has turned the primary attention to a negotiative character of knowledge production. The problem of what kinds of contracts can be made, with whom and on what conditions has been left open (Jacob, 1997).

Surely, it is possible to establish many types of collaborations but the problem of knowledge production cannot be solved only in this way. For instance, accordingtoJacob (1997:41) innovationsin the transdisciplinary groups are often only the result of tinkering and reverse engineering of established methods and theories from disciplinary science. There is also a need to discuss the relevance of the concepts of technology and innovation. As Allardt (1998a) has pointed out, technology provides no comprehensive and valid visions for the development of social, political and economic issues as it mostly provides limited technical solutions for complicated social problems (see also Ziman, 1996). At the same time innovation cannot be used to illustrate scientific process. It refers to new practices, deviations of old routines or adaptations to new situations. Revolutionary transformations which have almost always been sketched in the visions of technology policy can be accomplished only by changing social, political and economic structures. These structures cannot be influenced only by technology.

\section{Influence of Innovation Policy to University Policy in Finland}

Some Characteristics of Finnish

University Policy

Today there are 20 universities in Finland, mostly multifaculty universities 
and those specialised in technical and commercial sciences, but also four art academies. All universities have been state-run since the 1970s. The old universities are located at the largest cities. The new universities were mostly created during the reformist policy of the welfare state which had closelinksto the aspirations of regional policy. The Cabinet Programs and strategies argued for equalisation of opportunities and for the universities to have an impacts on local social, economic and cultural issues.

In 1990s the government authorities have made an effort to reorganise the dispersed university structurethat comprises too many small units. As the undermining of regional policy has been a politically sensitiveissue, thelatest Cabinets, the Ministries of Education and Finance and many government committees have stressed the importance of individual universities in constructing their own profiles as well as eliminating disciplinary overlapping and inefficient academic activities. As the universities are now in a constant stage of transformation together with the public sector, their position in the markets of knowledge-based services is problematic.

As all the universities in Finland are state-run, their goals have been defined in individual university laws. The latest statutes were passed in 1997 (645/97) comprising for the first time all the universities. On this level the state policy is liberal and there is awareness of the peculiarities of academic activities: free research and education are seen as the primary university functions. However, the university administration has now been opened to external actors and there is a pressure to create new forms of control after external evaluation was made obligatory and performance indicators of individual universities were linked to their share of government funding. Although the economic depression of the early 1990s has now changed to economic growth, there is still pressure on the universities to compete for decreasing government funding, to elaborate new selective processes and to find out external sources of financing. This has been experienced as exceptional in Finland, as thegovernment authorities have not been interested in making rankings and it has been out of the question for the universities to search for private money since the 1970's.

Along with the rise of neo-liberal ideology in the 1990s, the governments have launched the idea of competition in the context of the strategies of deregulation and self-regulation (Cabinet Programs in Finland 1987-1999; Ministry of Education, 1996). These strategies refer to a new definition of academic autonomy: a lump sum budget is regarded as increasing the university's independence in making decisions of operational funds. Self-regulation indicates also a demand for becoming morecompetitive and to end up in an agreement with government goals. All universities aretoday pushed to redefine their goals and to judgethebalancebetween thegoalsand results of their activities. The input/ output ratio is central in their performance negotiations with the Ministry of Education (Alestalo, Snell \& Pohjonen, 1997; Kaukonen \& Nieminen, 1997).

Due to strong political connotations the state has al ways been an important actor in the issues of higher education in Finland. The accomplishment of the welfare state program was a centralised attempt by the state to regulate the ex- 
pansion of the university system but also to penetrate into the affairs of economic and industrial policies (Alestalo, 1993). Along with the neo-liberal orientation the governments have madeattempts to search for redefinition of stateresponsibility and to develop moreeffectivepublic activities (Cabinet Programs in Finland, 1995; 1999; Ministry of Trade and Industry, 1996). Even though stateintervention in socio-economic issues is still seen as a legitimate effort, the state in Finland has made an effort to assist in the socio-economic adaptation process aiming at maximising the growth of the economy. At the same time it has made efforts to minimise the defects of the markets, promote the components of national competitiveness in European and world markets, and build a relevant infrastructure for economic activities. The undermining of the welfare state program has also activated discussion among the political elite about the role of the third sector. Until now this idea has been used mostly in a hypothetical way.

Reorientations in National Technology Policy

Industrial modernisation was a slow process in Finland. However, since the late 1980s technological development has been rapid. In the late 1990s there is a strong political consensus, marketed by the President of the Republic himself (Ahtisaari, 1997), about Finland as being one of the leading countries in the field of information and tele communication technologies (Ministry of Finance, 1996; Sitra, 1998). This view is based on a conception of these technologies as the most evolving clusters among other na- tional industrial clusters.

In a mature industry big companies havein general been state-owned. Today the neo-liberal orientation of the government can beseen in the privatisation of the state-owned companies. Prime Minister Lipponen's first Cabinet (199699) made a decision to allocatea significant amount of the money coming from the privatisation of firms to scienceand technology. The decision has been implemented by cutting public funds from the universities and by allocating more funding to theTechnology Advancement Centre and the Ministry of Trade and Industry to finance technology policy relevant research and education.

Since the 1980seconomic and industrial policy preferences in Finland have been increasingly concentrated on adjusting to economic changes. In the late 1980s economic policy became more aggressive and internationalisation and especially the joint European markets were regarded as the primary means for modernisation. The universities were integrated into this process by emphasising the beneficial impacts of international academic activities to societal progress. In the view of the Board of Education of Industry (1986):

There is a need to promote cooperation between the universities and the society... The universities should become members of respectable international scientific communities. Through their international contacts they can promote the attempts of the Finnish economy in its strivings to find new international markets.

In the middle of the 1990s the aims of technology policy have penetrated in a more systematic way into university policy. The increasing interplay between 
neo-liberal government policy and science and university policies have resulted in the launching of result-based management, cost-effectiveness and development of university-industry linksand contracts. The Council for Scienceand Technology Policy which comprises representatives from thescientific community and from the political and economic elite under the leadership of the Prime Minister, emphasised in its program "Finland, a Country of Knowledge and Competence" (1993) innovation as a challenge for socio-economic progress, for science and technology policies as well as for university policy. In its "Vision for Industrial Policy" from 1996 the Ministry of Trade and Industry argued for the coming of a world-wide technical and economic revolution that is based on globalisation and on the breakthrough of new technologies.

Today the scenarios of technology policy in Finland are full of expectations of radical renovations of social and economic structures. A concept of national innovation system has also been elaborated with a growing emphasison inputs to education and research and on the diffusion and utilisation of new technologies. The national innovation system has been regarded to provide direct impacts on university-government-industry links. Contrary to the earlier view of the importance of international academic recognition as serving the rapprochement of university to society, the current definitions of national innovation system have resulted in an one-dimensional conception of academic activities. In fact the universities are in the middle of two different kinds of pressures. The Academy of Finland (being the primary source of funding for aca- demic research in Finland), the Ministry of Education and many universities themselves havelaunched competitions of top units in research and education, for them to reach the international scientific front. The universities are also pressed to become more utilitarian and pragmatic, and to be aware of their input and output measures. However, there has not been analytic discussion on what the promotion of the national innovation system actually means and what kinds of effects this kind of national reorientation can have (Allardt, 1995).

Along with the redefinition of state responsibility, theaims of industrial and technology policies have been specified to accomplish an efficiency-driven strategy to eliminatemarket failures. According to the Ministry of Trade and Industry (1996: 11-14) the most important requirements of this strategy are competition, good conditions for capital markets and sufficient input in research and education.

Furthermore, the vision of the information society has been used to underlinethe importance of new technologies and skills as the motors of economic growth ( Ministry of Finance, 1996; Sitra, 1998). The origins of these components are in the innovation system that is based on a network of enterprises, research institutions, educational system, financingorganisationsand expertservices. To be successful, the innovation system should be based on new specialities but also on incentives to promote technological progress.

In current economic and industrial policies an attempt has been made to renovate regional policy. The aim is to establish regional growth centres with knowledge-based enterprises and in- 
dustries and new models of collaboration with the universities. National goals of technology/innovation policy follow the guidelines of the OECD and the EU by referring to the information society and the knowledge-based economy. There seems to be an agreement about innovations comprising all the stages of an innovation chain from the problem setting to the marketing of respective products and services and the university isseen as only one partner amongmany others in the innovation creation process.

\section{Different Universities, Different Goals and Missions}

Irrespective of an increasingtendencyto see the European universities as serving commercial aimsand values, the majority of the universities in Finland havenot profiled according to the dominant view of innovation policy. In general, they have not chosen their priorities to fulfil specific demands of firms or industry. However, as their activities are regarded important for economic and industrial activities, it is necessary to scrutinisethe concept of innovation to search for its relevance for the actual production of academic knowledge

In the following I explore the priorities and strategies which various types of universities in Finland have elaborated in order to be responsive ${ }^{2}$. This kind of documentation may only reflect rhetoric of the universities' leadership. It is also problematic whether a university can be studied as a unit, when it is organised into faculties and disciplines. However, as the Ministry of Education has started to control academic performance and the balance between the goalsand results, the universities are increasingly regarded as units and their leadership as responsible for the overall performance of universities. The performance negotiations with the Ministry have also strengthened the position of the rectors. It is not insignificant how the universities officially present their activities. Therefore I shortly demonstrate the recent directions taken by three universities in Finland: University of Helsinki, Helsinki School of Economics and Business Administration and Helsinki University of Technology.

With its over 34000 students the University of Helsinki is a large and multidisciplinary university established already in 1640. Helsinki School of Economics and Business Administration, which was established in 1911, was the only private university of these threeuntil 1974, when the whole university system wasmadegovernment-regulated. It is of a medium size (over 3700 students) and quite homogeneous by its disciplinary structure. Helsinki University of Technology was established in 1908 and has now 13000 students. After a long debateon the academic value of applied sciences in Finland, technical sciences institutionalised as individual universities, whereas agricultural sciences and forestry were integrated into the University of Helsinki.

All three universities regard themselves as the leading universities in the respective fields in Finland. They are located in the capital region and have had therefore more national than local importance. Recently, the Helsinki region has become the growth pole in the national economy and there have been attempts to link the universities more systematically to the economic structures 
of the region. The rectors of the universities, the representatives of the enterprises and the members of the City Councils of the four cities and the Union of Uusimaa have paid attention to thegrowing concentration of highly educated labour force and high tech telecommunication firms in this area and to theneed to integratethethree universities more directly into this concentration process (e.g. the lectures presented during the Jubileum Seminar by the Union of Uusimaa and the University of Helsinki, 12 January 1999).

Searching for New Definitions for Old Academic Traditions: University of Helsinki

The University of Helsinki can beclassified as a traditional discipline-based university, even though it changed in the 1980s into a multiversity. The courses on continuing education and training have been the most expansi ve activities. University comprises basic and applied sciences belonging to 121 departments and research stations as well as to 16 independent institutions. The faculties are composed of disciplines in humanities, social sciences, science, medicine and agricultural sciences and forestry. A number of disciplines can be found in Finland only in the University of Helsinki. As a response to the current government-led reorganisation, theuniversity has radically renovated and cut funding from the Faculties of Medicine and Science (Häyrinen-Alestalo, Tuunainen \& Snell, 1998). Similar efforts of a minor scalehavebeen proposed by the Rector to the Deans of other Faculties.

As regards the relevance of the Triple Helix model the most important rela- tionship of the University of Helsinki is with the state. In general the university has been marketed as an autonomous institution having a national duty to advance culture and to be in the international scientific front. It has been loyal to thestate, although itserved as a model of an elitist university being too much concentrated on the capital area during the reformistexpansion of the university system. Currently the university has been successful in the competitions of top research units arranged by theAcademy of Finland and the Ministry of Education.

Along with the regionally orientated universities, the University of Helsinki is expected to assist thestatein theaccomplishment of innovation policy. As regards the university's ability to solve the problem of employment, theundermining of the public sector has had a more direct impact on the University of Helsinki than on the regional universities: all ministries and key government institutions being able to provide jobs and ask services are situated in Helsinki.

Recently, the university has pursued a more aggressive policy than before. Its leadership and other academic personnel have criticised the criteria of resultbased management of the Ministry of Education. Concomitantly, the university has funding principles of its own that take into account the importance of research as a basic academic function. Several self-evaluations have been made in the university and a research policy has been published (University of Helsinki, 1998a). In the document there is an emphasis on a free flow of scienceand a doubt is presented whether the university should respond to the Ministry's demands for a specific profile in research. 
The working group responsible for the research policy also discussed the problems of technology-driven research funding and external funding in general, concluding that the cuts of operational funding have diminished autonomy. At the same time external funds may promote autonomy as the university is no more overly dependent on the Ministry of Education. The growth of strategic research is not problematic if there are good possibilities to makeresearch with problems that arise from internal problem-settings of disciplines (University of Helsinki, 1998b: 18). According to this view there are no alternative models for knowledge production: the university is responsible for setting its goals so that they support scientific activities.

In recent years the University of Helsinki has responded to the requests of the Ministry of Education by elaborating new goals and missions. The latest documents (e.g. University of Helsinki, 1998b: 2) are attempts to stress the old traditional mission of a university and theimportance of true knowledge-based learning. Concomitantly,

the University of Helsinki aims at producing new knowledgeand competencies which are based on internationally recognised research and education... Highly qualified research should beintegrated into teaching... Researchdriven education is ableto motivate to adopt a scientific way of thinking that is a condition of a successful work as a scientist or as a holder of any other job.

The Rector has also pointed to the responsibility of the university for maintaining and struggling for the integrity of science against unethical means of competition (Raivio, 1998).

In the strategies of the university an attempt has been made to explain what is actually going on in the society and the economy. In general, the analyses of the main transformations are only rhetorical reflections of government's political rhetoric. Such slogans as "the premises of sustainable growth will be taken into account in all university activities" and "life-long learning becomes an issue of the university's basic functions" are used. "The University 2015"-working group (1996) is aware of the hard laws of competition and of the undermining of thewelfarestate, but it is unable to make a preciseanalysis of these pressures. The members say that the university is ready to struggle for the values of welfare and solidarity but they leave open what the growth of hard economic values means to the university and to the society in general.

More consistent reflections of socioeconomic demands for the university's goal-setting can be found from the discussions about academic expertise. Along with the aims to promote cultural needs and services, the construction of knowledgecenters which provide useful information for the public and private sectors is seen important (University of Helsinki, 1998b). Firstly, there are aspirations for making the co-operation between the university's departments, research units and faculties as well as between the universities in the capital region, more intensive. Secondly, there is an emphasison new international forms of co-operation, in particular in joint partnerships in the EU projects (in which the University of Helsinki has been thesecond most successful among all universities in Finland).

Thirdly, an attention has been paid to university-industry links to assist in the 
development of the "national innovation system". These efforts are on theone hand focused on teaching the research personnel individual property rights and entrepreneurial activities. On the other hand they haveresulted in theestablishment of university-owned companies. The main attention is on a project to create knowledge centers, by grouping the departments with relevant disciplines into new campuses, and to establish the Helsinki Science Park in the context of the campus comprising natural sciences, biosciences and agricultural sciences. Asmost of theseactivities areonly in the very beginning stages there has not been systematic discussion of their impacts on the traditional definitions of knowledge production or of the problems of commercialisation.

Even though there are many formal attempts to intensify university-industry linksat the university, most of theselinks aretoday moreindirect than direct. Also the Helsinki Science Park has been a long-term project with complexnegotiations with the state and the City of Helsinki about land owning and architectural solutions. Moreover, even though there have been discussions of the rapprochement of the university to high tech industries, the process is still in the phase of hopes and expectations. By tryingto answer this question the Chancellor of the University of Helsinki has listed the following issues that are worth of supporting (Ihamuotila, 1999):

- allocating basic funding to knowledge producers (the state)

- promoting the establishment of high tech firms (TE-centre, universities, the Union of Uusimaa)

- making the chains of innovation more effective (university-owned enterprises, universities)

- promoting continuing education (universities and other teaching institutions)

- establishing a Council for the Capital Region

However, despite various efforts to integrate the university into the activities of theenterprisesector, therepresentatives of the university want to limit their responsibility to the first phase of an innovation chain, i.e. to research that traditionally has been called academic. Therefore, the concept of innovation has not been experienced as problematic at the university and has not been discussed in a systematic way.

How to move from Practice-Orientation to Science-Driven Activities? Helsinki School of Economics and Business Administration

Traditionally Helsinki School of Economics and Business Administration (HSEBA) has been practice-orientated. The identity of the graduates has been reflected through a vocational identity even though it has not been precise. While the University of Helsinki is now moving towards more organised relationships with the enterprise sector, the representatives of firms havealways had an influence on the HSEBA's activities. They have been board members and have had influence by setting demands for education, following the employment rate of the graduates, providing jobs for the students and graduates, commissioning graduate theses as well as financing the professor chairs and various kinds of research projects. For this reason the relationship of the 
HSEBA to the government authorities has been until current performance negotiations more loose than the ones of the multidisciplinary universities. Most of the ideas of renovation have been adopted from evaluators who are recognised experts from international business schools rather than from the Ministry of Education (Alestalo, Snell \& Pohjonen, 1997).

Because of a strong practice-orientation the newly founded vocational colleges in Finland have been experienced at theHelsinki School of Economics and Business Administration ascompetitors. Thereseems also to bea competition for expertise markets between the HSEBA and private consulting firms. The activities of the HSEBA are based on a discipline structure comprising the Departments of Management, Accounting and Finance, Marketing, Economics and Language and Communication. The departments vary according to their size and orientation, the Department of Accounting and Financing being the largest but the least research-intensive. In recent years reorganisation has been accomplished after a discussion of disciplines of primary and secondary importance. Today management and marketing are considered as primary fields. (HSEBA, 1999a). A project is also going on to constructa business campusat the center of Helsinki.

Currently Helsinki School of Economics and Business Administration is in the middle of a turbulence. Foreign evaluators paid attention to its strong vocational orientation and now efforts have been made to make its activities more scientific. The aim isto becomea recognised member in the international and European scientific community in eco- nomics and business research. Research-orientation has al so been used as an argument in the last elections of the rectors: there is a new generation of professors being researcher-minded.

The formulation of new goals has been taken seriously in the HSEBA. In 1997 there was by the initiative of the Rector a long discussion of the values before the outlines of a new mission were specified. However, even though research-orientation has been mentioned first, the final list of values looks like a compromise from which all radical ideas are lacking. The latest mission is a mixture of responsiveness to scientific and pragmatic issues (HSEBA, 1999a:2). If a comparison is made to the mission published in 1996 (HSEBA, 1996:4) thereis a change towards a more coherent view of a science-based institution. The HSEBA, of which the term School was used previously, is also now referred to as a university that

has a national task to produce new knowledgein economics and business research and to establish cooperation with firms... The university aims at deepening national economic competencies and at acting as a forerunner... Themission includes a respectable position in the European research and teaching in the field... and a growing number of international cooperation in research and education.. The university is a provider of education and full services in its field. It aims at developingall central fields of economics and business administration and at being in cooperation with the national big firms, innovativeSMEs and international enterprises.

Along with the efforts to strengthen the scientific output of the HSEBA's academic staff, the Rector has adopted market analogies even more profoundly 
than whathas been expected by theneoliberally orientated government authorities. In his words, the primary goal is quality but not in the sense that it is defined in the mission of the University of Helsinki. In the HSEBA "quality means satisfying and exceeding customer's expectations" and the criteria are close to business firms' quality certifications. When for instance the Deans of the Faculties at the University Helsinki havedifficulties to identify the actual products of the departments and especially their social impacts, the Rector of the HSEBA easily lists the elements of quality and academic markets as well as the customers. In his words the search for markets pushes the HSEBA to attempt to find a balance between inputs and outputs and there is no conflict between the market expectations. The markets comprise the following components (Kasanen, 1996):

1. student recruitment

2. academic staff recruitment

3. administrative staff recruitment

4. long-term alumni careers

5. refereed academic research

6. research contracts

7. executive teaching

8. consulting

The Rector has signed a letter sent to the enterprises inviting them to usethe services of the HSEBA (1999b). The majority of HSEBA's activities have been commercialised in order to serve the market demands (LLT Research Ltd., Incubator Caduceus, Small Business Center, Center for Innovative Education, Student Business Projects and Case-Projects for thefirms; HSEBA, 1999b.). The establishment and reorganisation of these units reflect the official aims of innovation policy as attention has been paid to promoting growth of innovations, the building up of firm incubators and the concentration of innovative clusters of industrial production (HSEBA, Weakly Review, 15, 1998:6).

As regards knowledge production, there has been only some discussion about the problem of how science- and market-driven orientations can be realised at the same time. For example, the Helsinki School of Economics and Business Administration has not been very successful in national competitions of scientific excellence. Also its contributions to Finnish science and university policy have not been so high as that of the University of Helsinki or theHelsinki University of Technology.

The Rector's view of the current needs of socio-economic information is based on a conventional economist's view of education as a producer of investment capital. Moreover, in the visions of the HSEBA the European context is mostly linked to competition for the best students, who now have a good opportunity to go to Europe to be educated. In a market-driven system thestudentsareconsidered as the key customers of educational services. The main problem in the future is therefore seen to berelated to theneeds of these customers. What are the real opportunities to develop research-orientation if thestudents to choosehigher education in order to get good jobsin thebusiness firms and only a marginal part of them areinterested in scientific research? The traditional forms of business co-operation and the public image of theHSEBA as a market-driven institution may have dysfunctional effects. 
The Pressure to Adapt to Modern Technologies: Helsinki University of Technology

During its existencethe Helsinki University of Technology has witnessed Finland's development from a slowly industrialising agrarian society to high techdriven economy. Today the university has 12 departments comprising all key fields of technical sciences, 11 research and education units and 10 research institutes (Helsinki University of Technology, 1997). As the participation to all phases of an innovation chain has been experienced as problematic also in this university, it established in 1998 "Otaniemi International Innovation Center" "to concentrate dispersed innovativeactivities, to assist in the profiling of the university as a high tech-driven organisation, to market its products, to evaluate new technologies and to make the utilisation of research results more rapid". The university in close collaboration with Technical Research Centreof Finland (VTT) and it has joined to the efforts of other capital area universities to promote the visibility of Helsinki area as a high tech intensive growth pole.

TheHelsinki University of Technology has today solid relationshipsto thestate and theindustrial and economic sectors. In general the graduates from the university have had a central role in the industrialisation process. During the reformist period of the 1970s the university was transferred from the commission of the Ministry of Trade and Industry to that of the Ministry of Education. The strong state penetration into economic and industrial policies aroused conflicts between the Ministry of Education and the university as the Minis- try wanted to minimise the amount of private funding. Presently privatefunding to the university's activities is more notable than in the other universities of the capital area. The departments comprise also laboratories where all activities are dependent on the commercialisation of their products.

Due to its disciplinary structure the Helsinki University of Technology has a more detailed conception of the conditions and prospects of industrial development than the other universities. It has been one of the primary focuses of increased government funding through the Technology Advancement Centre. It has also had the largest number of partnerships in the EU projects. However, the cuts of operational funds have activated a discussion about the value of basic academic functions. The Rector has argued for the need to finance basic science and basic university functions (Uronen, 1998).

Themajority of theuniversities in Finland have responded to the reorganisation demands of the Ministry of Education by uniting small departments and by abolishing activities of "secondary importance". The Helsinki University of Technology has experienced a different sort of a pressure. The rapidly growing needs of education and research in telecommunication technology (Nokia Company) have increased student admission and the number of professor chairs in the respective disciplines. The two departments from 1981 representingthese fields have been renovated and comprise now five departments. At the same time the number of professor chairs at these departments has grown from 36 to 101 (professors and assistant professors; Helsinki University of Tech- 
nology, 1982; 1998b). This growth has been so rapid that in the strategies of the university the limits of an one-sided expansion have been discussed. Should the university respond to the seemingly indefinite needs for education in telecommunication industry? What kinds of effects thistype of centralised expansion will have to the other fields of technical sciences?TheStudent Union of the university has also paid attention to the power struggle between various interest groups. More important than trying to respond to all interest controversies is to discuss what kinds of technologies, policy-makers, researchers and teachers will be needed in the future (Mantere, 1998).

TheHelsinki University ofTechnology (1998a) has specified itssocio-economic role which is almost identical with the guidelines of the official technology and innovation policies. Accordingly,

the university has a responsibility to assist the promotion of the national innovation system. It is responsible through scientific research for producing new technological knowledge, for taking care of the transfer of scientific knowledge and technology to the use of society, and for promoting the creation of new enterprises. In particular the university will support thecompetitiveness of national industries. It will evaluate thestate of global and national technologies and the possibilities and impacts of technology. The university will scrutinise critically its results and role as an actor in the technological development of the society.

Accordingly, on the level of goals and mission an attempt is made to integrate the demands of innovation policy into knowledge production. The primary function of theUniversity of Technology isto produce new scientific and technological knowledge, provide education that is based on the mostrecent research results and to be self-critical. The link from the university to technology is through scientific research. However, as the key ideas of technology policy are repeated almost identically in the university's own strategy, there is nothing original and analytic in the reasoning.

On the other hand, the discussions with the personnel of the laboratories who are active in the commercialisation of their activities, reveal the need to discuss the peculiarities of engineering knowledge. An engineer illustrated his approach in the following way: "In an enterprise there is some need for a change. I can solveit, write about it, calculate it, think about it and analyse it". So the engineering approach starts from the idea that problems are simple and solvable. There is no need to search for relevant theories or to set complicated hypotheses. If engineeringknowledgeis set in the context of innovation, it comes more easy to view the various stages of an innovation chain as a coherent process. However, even though in this case the production of knowledge and its commercialisation may seem to beclose to each other, there is not necessarily a need for a negotiativeform of knowledge production. An engineer may also be quicker to solve theneeds of change, but is knowledge he/ she is able to produce "better" than a moreacademic one?This notion is also related to the problem of how to find a balancebetween scientific orientation and the growing demands for producing innovations. 


\section{Conclusion}

The analysis of the universities as contributors to and implementators of government technology and innovation policies draws a complicated picture. The universities, being the primary producers of knowledge have responsibilities which cannot be madeinto marketdriven products. Otherwise it will bedifficult to legitimate universities' value as an academic institutions. Therefore, the transparency of technology policy and the political formulations of innovation cannot betaken uncritically as the future criteria.

Thepromises of technology and innovation policies are an attempt to regard the integration of science and higher education with the components of economic progress as visionary. In a way this is an old view of the state which is now used in a new political context. The ongoing undermining of government responsibilities and the pressure to commercialiseall kinds of products and services are results of the neo-liberal ideology. When the nation-states and the EU try to act as mediators of interests, their efforts do not mean that they are neutral actors, able to respect the whole multiplicity of interests. On the contrary the redefinition of academic functions point to a pressure to develop negotiative models of knowledge production that are often pragmatic queries of high economic utility.

Today various missions and strategies are taken as evidences of the policymakers' capability to estimate socioeconomic development in the future. Strategies belong to the methodological repertoire of future studies aiming at minimising therisk of makinginvalid es- timations. At first sight they seem to be based on a theory of social change, but in fact are close to political programs, which can be easily changed into new ones without paying attention to the long-term impacts of these changes.

Theanalysis of thegoalsand missions of the three universities demonstrates many interesting issues. Firstly, as strategy-makers theuniversities havea vague role in society as they take the ideas of economic and technology policies mainly as given without developing new models on the basis of their scientific competence. Irrespective of the rise of a moreaggressiveapproach, thereisa lack of discussion of the real needs of reform at the universities.

Secondly, therelationship to thestate has always been problematic to the Finnish universities. Beside neo-liberal ideas of individualisation, the government expects the universities to beloyal in a new way. Among others cost-effectiveness and performance negotiations point more to the means of government control than to an increase of self-regulation. The cuts of public budgets have also pushed the universities to pay attention to the issues of reorganisation. To be progressive these reorganisations should beaccomplished byconsidering the capability of the universities to develop as true scientific institutions. The case of Helsinki School of Economics and Business Administration indicates that although it may look functional to see potential markets for academic products everywhere, the market demand is dependent on a solid scientific basis.

It seems that a kind of "back to basicsstrategy" is needed to strengthen the universities as academic institutions. 
The examples of the University of Helsinki and the Helsinki University of Technology imply that the responsiveness to new economic pressures is dependent on the scientific identity of the university. One can even say that if the scientific community regards a consulting type of knowledge as a competitor, the university has failed to legitimate its social value. Already earlier the critics of the multiversity warned the universities of not going to all directions at the expense of their identity. This requirement points to a need to discuss the limits of the "hybrid" forms of co-operation and technology-driven knowledge production.

\section{Notes}

1 TheprojectEVALUE (Evaluation and SelfEvaluation of the Universities in Europe) was financed by the European Commission in 1996-1998, with partnersfrom Finland, France, Germany, Italy, Norway, Portugal, Spain and theUK. TheFinnish team comprised the Research Group for Comparative Sociology at the Department of Sociology, University of Finland (Häyrinen-Alestalo, Snell and Tuunainen) and Science Studies Unit at the Research Institutefor Social Sciences, University of Tampere (Kaukonen and Nieminen).

2 This article is part of the projects "Conditions and Controversies of Modern Knowledge Production" financed by the Academy of Finland and "Innovation Policy and the Changing Logics of Action of the Universities" financed by the Ministry of Tradeand Industry. Along with the macro level policy analyzes, the projects will comprise department level analyzes of the three universities, especially in the field of social sciences. The latter project is a joint effort by the Research Group of ComparativeSociologyat the Department of Sociology, University of Helsinki (Häyrinen-Alestalo, Snell, Pelkonen, Pel- tola, Tupasela) and the Department of Management at Helsinki School of Economics and Business Administration (Räsänen, Mäntylä).

\section{References}

Ahtisaari, Martti

1997 "Suomen kehittyminen tietoyhteiskunnaksi - kansallinen hankkeemmeja eurooppalainen tehtävämme" (Finland's Development to thelnformation Society- our National Effort and European Duty). The Lecture in "Studia Finlandica" 20.03.1997. Helsinki: University of Helsinki.

Alestalo, Marja

1993"Scienceand theWelfareStateProgram: The Growth of State Activism in Finland". Knowledgeand Policy. The International Journal of Knowledge Transfer and Utilization, 6, 1: 52-66.

1997 "Variations in State Responsiveness. The Science System and Competing Theories of the State". International Sociology, 12, 1: 73-92.

Alestalo, Marja, Snell, Karoliina and Pohjonen, Tapani

1997 Evaluation at the Helsinki School of Economics and Business Administration. Third CaseStudy. EVALUE (Evaluation and Self-Evaluation of theUniversities in Europe). European Commission. DGXII. Program TSER. AXII: Contract SOE2- CT95-2004. Paris.

Allardt, Erik

1995 "Kansallinen innovaatiojärjestelmä teknologiapolitiikan ystävänä ja tiedepolitiikan haittana" (National Innovation System as a Friend of Technology Policy and as a Constraint for Science Policy). Tieteessä tapahtuu, 4: 5-9.

1998 "Teknologiapolitiikka suomalaisen todellisuuden konstruoimisen välineenä" (Technology Policy as a Means to Construct Finnish Reality). Tiede \& Edistys, 2: 85-95.a.

1998"Utvärdering- en bådeinom- och utomverksamhet" in L. Åberg (ed.) Utvärdering- ett medel för att säkra eller utveckla kvalitet. Forskningsnämnden. Rapport 98, 1: 23-28. Stockholm.b. 
Blair, Tony

1998 Our Information Age. The Government's Version (Summary). http:// www.number-10.gov.uk/ public/info/ releases/publications/ infoage.feat. html.

Board of Education of Industry

1986 Teollisuuden koulutuspoliittisia linjoja (Outlines of Educational Policy of Industry). Helsinki: Suomen työnantajainkeskusliitto, Teollisuuden keskusliitto. Cabinet Programs in Finland, 1987-1999.

Castells, Manuel

1996 The Rise of Networked Society. The Information Age: Economy, Society, Culture. Vol. I. Oxford: Blackwell Publishers.

1997The Power of Identity. Malden \& Oxford: Blackwell Publishers.

Coleman, James S.

1990 Foundations of Social Theory. Cambridge, Massachusetts: Belknap Press of Harvard University Press.

Council for Science and Technology Policy

1993 Tiedon ja osaamisen Suomi. Kehittämisstrategia. (Finland - A Country of Knowledgeand Competence. A Development Strategy). Helsinki

Cresson, Edith

1996 "Innovation, Europe's Achilles Heel". The IPTS Report, 7: 1-2.

Etzkowitz, Henry, Webster, Andrew and Healey, Peter (eds.)

1998 Capitalizing Knowledge: New Intersections of Industry and Academia. New York: State University of NewYork Press.

Etzkowitz, Henry and Leydesdorff, Loet

1998 "The Triple Helix as a Model for Innovation Studies". A paper presented at the 14th World Congress of Sociology, Montréal, Canada, 26July- 1 August.

Europe:TheThirdWay/DieNeueMitte-Tony Blair and Gerhard Schoeder

1999. Labour Party. Documents. Http:// www.labour.org.uk/index.html.

European Commission

1994 Growth, Competitiveness, Employment. The Challenges and Ways Forward into the 21st Century. White Paper. Brussels-Luxemburg: ECSC-ECEAEC.
1995 Green Paper on Innovation. December. 1998 The Globalising Learning Economy: Implications for Innovation Policy.

EVALUE

Luxemburg: European Communities.

1998 Final Report

Fuller, Steve

1998 "A Myth of the Modes: A Critique of the New Production of Knowledge Thesis. A Lecturein theAnnual Seminar "Studies of Science" organized by the Finnish Society for Science Studies, Helsinki, 29-30 October.

Gibbons, M., Limoges, C., Nowotny, H., Schwartzman, S., Scott, L. and Trow, M.

1994TheNew Production of Knowledge: The Dynamics of Science and Research in Contemporary Societies. London: Sage. Giddens, Anthony

1998 The Third Way. The Renewal of Social Democracy. Oxford: Polity Press \& Blackwell Publishers Ltd.

Grossman, G. M. and Helpman, E.

1991 Innovation and Growth in the Global Economy. Michigan: MIT Press.

Gueissaz, Albert and Häyrinen-Alestalo, Marja

1999 "How to Integrate Contradictory Aims. The Configurations of Actors in the Evaluation of the Universities". European Journal of Education, (forthcoming).

Gueissaz, Albert, Häyrinen-Alestalo, Marja, Fischer-Bluhm, Karin and Snell, Karoliina

1998 "TheActors of Evaluation. The Decision to Evaluate. In EVALUE (Evaluation and Self-Evaluation of the Universities in Europe). Final Report. European Commission. Contract SOE2-CT95-2004. Project 2001. 31 July: 154-180.

Helsinki School of Economics and Business Administration

1996 Toiminta- ja talousuunnitelma 19972000 (A Plan for Activities and Financing).

1999a Vuosikertomus 1998 (A Yearly Report 1998). Helsinki: Yliopistopaino.

1999b Helsingin kauppakorkeakoulu yrityksesi palveluksessa (Helsinki School ofEconomics and Business Administration in the Service of Your Firm). 
Helsinki University of Technology

1982Toimintakertomus 1981 (Annual Report 1981). Otaniemi.

1997Toimintakertomus 1997 (Annual Report 1997). Teknillinen korkeakoulu.

Hallintoviraston julkaisuja 4.

1998 Home page in Internet. TKK 2005. Strategia (Strategy).a.

1998 Basic Data for the KOTA-Data Basis.b. Häyrinen-Alestalo, Marja

1999"Is Knowledge-Based Society a Relevant Strategy for Civil Society?" In K. Adhikari \& A. Sales (eds.) Knowledge, Economy and Society. (forthcoming).

Häyrinen-Alestalo, Marja and Snell, Karoliina

2000 Pushing the University to Search for Markets for Its Products: Obsrvations from Europe and Finland. In R. Kalleberg \& R. Steen Jensen (eds.) Comparative Perspectives on Universities and Production of Knowledge. Comparative Social Reseach. AYearbook. (forthcoming).

Häyrinen-Alestalo, Marja, Tuunainen, Juha and Snell, Karoliina

1998 First Case Study. The University of Helsinki. RevisedVersion. EVALUE (Evaluation and Self-Evaluation of the Universities in Europe), European Commission. DGXII.Program TSER. Area II. ContractSOE2-CT95-2004. Paris. http:/ / www.infobase.it/InfobaseEvalue.htm Ihamuotila, Risto

1999 "Tiede ja teknologia Uudenmaan voimavarana" (Scienceand Technology as Competencies of Uusimaa). A Speech at Studia Uusimaa organized by Union of Uusimaa and University of Helsinki. Helsinki, January 12.

Jacob, Merle

1997 "Life in the Triple Helix: The Contract Researcher, the University and the Knowledge Society", Science Studies, 10, 2: 35-49.

Kasanen, Eero

1996 "Laadun logiikka" (The Logics of Quality). Puhe Helsingin kauppakorkeakoulun avajaisissa, 30.8.1996. Helsingin kauppakorkeakoulu: 1-19.
Kaukonen, Erkki and Nieminen, Mika

1997 Second Case Study. University of Tampere. EVALUE (Evaluation and Self-Evaluation of the Universities in Europe), European Commission. DGXII. Program TSER. Areall. Contract SOE2-CT95-2004. Paris

Lefèvre, Theo

1965 "The Ministerial Meeting on Science", in OECD, Ministers Talk about Science. Paris: OECD.

Leydesdorff, Loet and Etzkowitz, Henry

1996 "Emergence of a Triple Helix of University-Industry-Government Relations". Science and Public Policy, 23, 1: 279286.

Mantere, Saku

1998 Puhe Teknillisen korkeakoulun avajaisissa (A Speech in the Opening Ceremony of Helsinki University of Technology). 10.9.1998: 13-15.

Ministry of Education

1996 Yliopistojen tulosohjauksen kehittäminen. Yliopistolaitoksen tulosohjauksen kehittämistyöryhmän raportti (Development of Result-Based Management at the Universities). Opetusministeriön työryhmien muistioita, 36.

Ministry of Finance

1996 Finland's Way to the Information Society. The National Strategy and its Implementation. Helsinki: Ministry of Finance.

Ministry of Trade and Industry

1996 Teollisuuspoliittinen visio (A Vision for Industrial Policy). Kauppa- ja teollisuusministeriön julkaisusarja, 2, Helsinki.

1997 Teknologian tutkimuksen ohjelma. KTM:n ja Tekesin rahoittaman teknologian tutkimuksen puitteet vuoteen 2001 (Technology Research Program). Kauppa- ja teollisuusministeriön julkaisuja, 10.

Nieminen, Mika

1998 "Transepistemic Arenas and New Modes of Knowledge Production". A paper prepared for the EASST ' 98 Conference on "Cultures of Science and Technology: Europeand thetheGlobal Context, Lisbon, Portugal ,1-3, October. 
OECD

1988OECD Ministers Talk about Scienceand Technology for Economic Growth and Social Development. Paris: OECD.

1996 Technology, Productivity and J ob Creation. Paris: OECD.

Offe, Klaus

1996 Modernity and the State. East, West. Cambridge: Polity Press.

Raivio, Kari

1998 "Maailma muuttuu - muuttuvatko yliopistot? (The World is Changing Will the Universities Change?), Yliopisto 6: 5-7.

Richta, Radovan

1977 "The Scientific and Technological Revolution and the Prospects of Social De velopment", in R. Dahrendorf (ed.) Scientific-Technological Revolution: Social Aspects. Guilford: Sage Publications.

Rojo, Jaime

1996 "Economic Growth Theories and Technical Change". The IPTSReport, 5, 1: 3337.

Romer, P.

1986 "Increasing Returns and Long-Run Growth". Journal of Political Economy, 5, 94.

Sitra

1998 Elämänlaatu, osaaminen ja kilpailukyky. Tietoyhteiskunnan strategisen kehittämisen lähtökohdat ja päämäärät (Quality of Life, Competence and Competitiveness of theEconomy). Helsinki: Sitra 206.
Soete, $\mathrm{L}$.

1996 "The Challenges of Innovation". The IPTS Report, 7: 7-13.

University of Helsinki

1996Yliopisto 2015-työryhmän raportti (The Report of the University 2015-Working Group). Helsingin yliopiston toimikuntien selvityksiä, 65.

1998 Helsingin yliopiston tutkimuspoliittinen ohjelma 1998. (The Program for Research Policy of the University of Helsinki 1998). Helsinki. a.

1998Toiminta- jatalousuunnitelma (tarkiste) vuosiksi 1999-2000. (A Plan for Activities and Financing, Revised Version, for the Years 1999-2000). Helsinki. b.

Uronen, Paavo

1998 "Avajaispuhe" (Opening Speech). Teknillisen korkeakoulun lukuvuoden avajaiset. 10.9.1998: 5-12.

Viale, Riccardo and Ghiglione, Beatrice

1998 "The Triple Helix Mode: A Tool for the Study of European Regional Socio-Economic Systems". The IPTS-Report, 29: 34-37.

Ziman, John

1996 "'Postacademic Science'. Constructing Knowledge with Networksand Norms". Science Studies, 9, 1: 67-80.

Marja Häyrinen-Alestalo

Department of Sociology

University of Helsinki

Helsinki, Finland 